\title{
Matoniaceous ferns from Lower Jurassic strata of the Holy Cross Mountains (SE Poland). Revision of historical specimens and description of some new materials
}

\author{
GRZEGORZ PACYNA \\ Jagiellonian University in Kraków, Faculty of Biology, Institute of Botany, Department of Taxonomy, \\ Phytogeography and Palaeobotany, Gronostajowa 3, 30-387 Cracow, Poland; \\ e-mail: grzegorz.pacyna@uj.edu.pl; ORCID 0000-0003-4365-3549
}

Received 9 April 2021; accepted for publication 7 June 2021

\begin{abstract}
Ferns from the family Matoniaceae are characteristic but not very numerous elements of Early Jurassic floras of the Holy Cross Mountains. Based on historical specimens from the Geological Institute of the Polish Academy of Sciences, only partly published by Raciborski and Makarewiczówna, and a new collection gathered recently from the Gromadzice outcrop, two taxa are here recognised: Matonia braunii and Phlebopteris angusti$l o b a$, of which only $P$. angustiloba is rather frequent. Both species are represented by sterile and fertile specimens well comparable with historical and recently published material of these species from Greenland, Germany and Sweden. Specimens referred by Raciborski to Laccopteris elegans (illegitimate name) do not belong to Matoniaceae.
\end{abstract}

KEYWORDS: Matonia, Phlebopteris, Hettangian, Gromadzice

\section{INTRODUCTION}

The fern family Matoniaceae is a characteristic but only locally numerous and moderately taxonomically diversified element of Mesozoic floras from the Late Triassic to Cretaceous, becoming more and more relictual in the Cenozoic (Schweitzer, 1978; Tidwell and Ash, 1994; Popa, 1997; Taylor et al., 2009). The most characteristic features of the family include pedate fronds with pinnate pinnae and sporangia arranged in sori, with or without a peltate indusium (Kramer, 1990; Taylor et al., 2009). This family is well represented in Early and Middle Jurassic floras of southern Poland (Raciborski, 1894; Pacyna, 2013). The following genera were documented: Matonia R. Brown in Wallich, Matonidium Schenk and Phlebopteris Brongniart (=Laccopteris Presl in Sternberg) (Raciborski, 1891, 1892, 1894; Makarewiczówna, 1928; Reymanówna, 1963;
Barbacka et al., 2010, 2014, 2016; Pacyna, 2013). Published research (Barbacka et al., 2014, 2016) and ongoing work on Matoniaceae from the Polish Mesozoic (Holy Cross Mountains area, Grojec locality) has indicated the need to revise historical specimens, as new data about this family have been amassed in recent years (Van Konijnenburg-van Cittert, 1993; Badihagh and Uhl, 2019; Barbacka et al., 2019; Van Konijnenburg-van Cittert et al., 2020) and there has been progress on taxonomical issues (Harris, 1980; Klavins et al., 2004; Kvaček and Dašková, 2010).

Early Jurassic plants from the Holy Cross Mountains were among the first-described fossil plants from Polish territory. In two papers, M. Raciborski (1891, 1892) described several species from the Ostrowiec Świętokrzyski area. Makarewiczówna (1928) revised some 
material published by Raciborski and described additional later-collected specimens. Modern research on this flora began with the discovery of the Odrowąż (Sołtyków) locality in the 1970s (Reymanówna et al., 1987). Based on these specimens and new material from boreholes, several papers have been published since then (Ziaja, 2006; Barbacka et al., 2010, 2014, 2016), and new specimens from historical localities such as Gromadzice have been collected recently (Pacyna and Zdebska, 2011; Pacyna et al., 2018). Pacyna (2013) summarised the history of that research and collated a list of recognised taxa. Despite this revival of research on Early Jurassic plants from the Holy Cross Mountains, the material published by Raciborski has not yet been revised. The collection gathered for him includes, besides the specimens he published, numerous specimens that were not registered and described. Revision of this material is important for many reasons. It includes specimens from now-inaccessible outcrops, some well-preserved examples, and some specimens on which Raciborski based proposals of new taxa. Some interpretations and the nomenclature used are outdated, however, and need revision. The historical collection of Early Jurassic plants from the Holy Cross Mountains stored in the Geological Institute of the Polish Academy of Sciences is the largest one still available. The fate of most specimens described by Makarewiczówna (1928) is unknown; probably they are lost. In the mentioned collection I identified some of the specimens she illustrated. Her collection in the Institute of Botany of the Jagiellonian University probably is incompletely preserved; no specimen could be identified with confidence as illustrated by her. We do not know the whereabouts of specimens from the Polish Geological Institute in Warsaw (J. Czarnocki collection) and from the no-longerexisting S. Batory University (B. Rydzewski collection) in Wilno (today Vilniaus Universitetas in Vilnius, Lithuania). Specimens collected and listed by Kuźniar (1923, 1924) probably were lost during World War II.

This paper revises published and unpublished historical specimens of matoniaceous ferns from Lower Jurassic strata of the Holy Cross Mountains. Some specimens published by Raciborski (1891) do not in fact belong to this family and will be the subject of forthcoming research; several specimens so far unpublished turned out to belong to the Matoniaceae and provided fine, important morphological details. Some historical specimens of this family from the region could not be revised for the reasons enumerated above. A matoniaceous specimen (positive and negative of one pinna) from a new collection from Gromadzice is also here described. This is the first paper describing material from recent excavations in Gromadzice in detail.

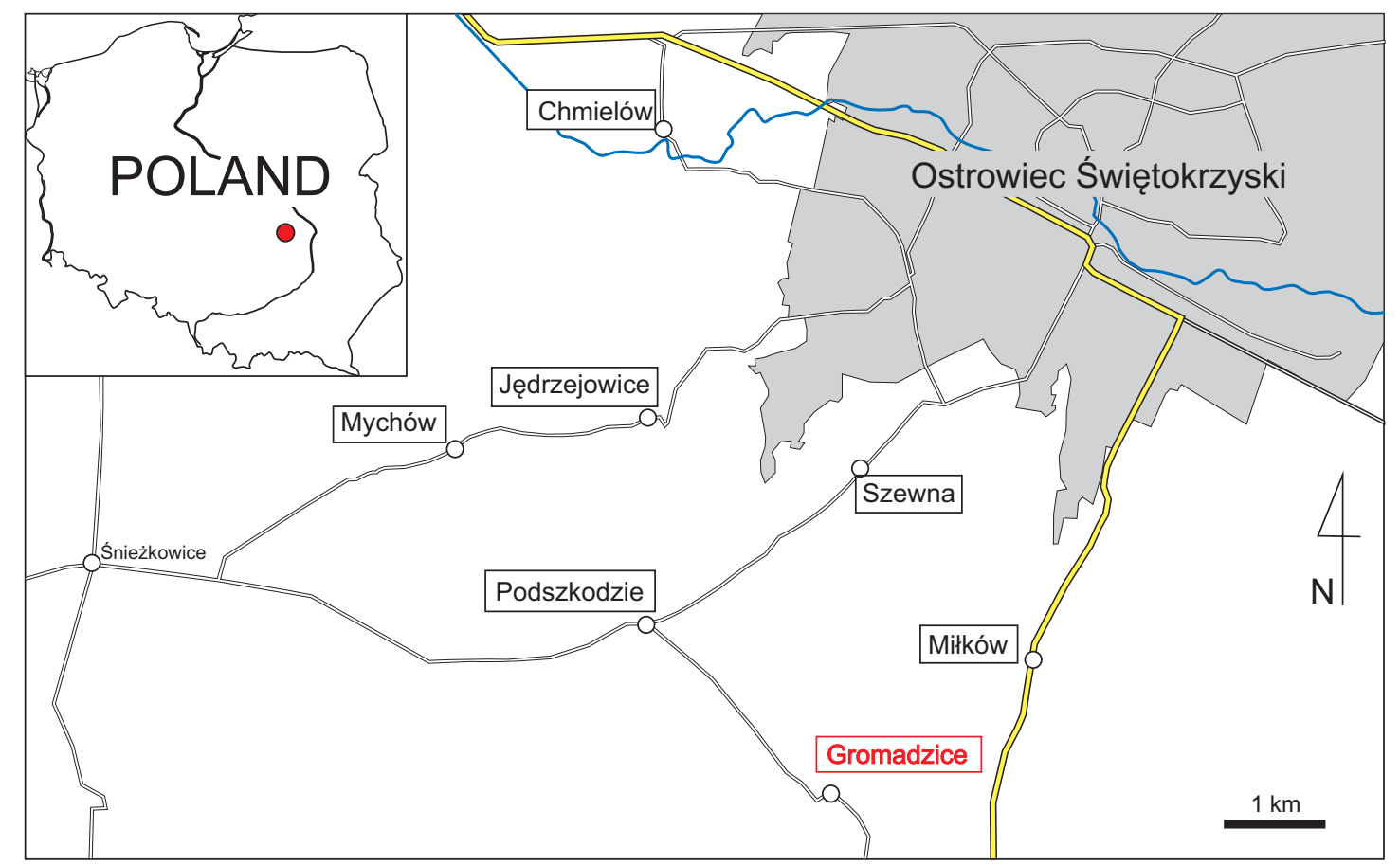

Fig. 1. Map showing Lower Jurassic plant-bearing localities in the Ostrowiec Świętokrzyski area, including those from which the described material originates (Gromadzice), and the location of the investigated area in Poland 


\section{GEOLOGICAL SETTING}

Lower Jurassic sediments are well exposed in the Ostrowiec Świętokrzyski region in the Holy Cross Mountains (Pieńkowski, 2004, 2006). Many outcrops with fossil plants were accessible at the end of the $19^{\text {th }}$ century (e.g. Gromadzice, Miłków, Mychów, Jędrzejowice, Chmielów, Szewna, Podszkodzie; Fig. 1). Among these, Gromadzice provided most specimens of a well-preserved flora, but today it is not possible to determine with certainty the exact sites where the specimens Raciborski described were gathered. Two outcrops are still accessible: the Gromadzice lower outcrop with the uppermost part of the Zagaje Formation exposed, and the Gromadzice upper outcrop with sediments of the Skłoby Formation; identifiable plant remains are present only in the former (Fig. 2). The lower outcrop in Gromadzice is on the bank of Kamionka Stream. The outcrop reveals a sequence of an alluvial depositional system and an upper delta plain depositional subsystem (Pieńkowski, 2004: fig. 11, 2006: fig. B4.14). The change in the depositional system from alluvial plain to delta plain is gradual. The lower part of the outcrop comprises a meandering alluvial channel subsystem with trough-cross bedded sandstone filling channels. The overlying complex is composed of grey laminated mudstones, siltstones and grey fine-grained sandstones. Its characteristics point to an upper delta plain deposit, where the muddy overbank plain was periodically occupied by brackish water. Sandstone/siltstone layers represent deltaic, basinwards-prograding crevasse splay depositions. These features are consistent with rapid aggradation during which crevassing lacustrine/marsh sedimentation and avulsion dominated the delta plain/ floodplain. Most plant macrofossils from the lower outcrop in Gromadzice are preserved in crevasse splay deposits. Numerous specimens were gathered from this outcrop recently (Pacyna et al., 2018), but only one matoniaceous fern specimen was found. This assemblage is dominated by leaves and cones of ginkgoaleans and czekanowskialeans (Sphenobaiera, Czekanowskia). Other taxa such as sphenopsids (Neocalamites), ferns (Cladophlebis, Matonia, Dictyophyllum), seed ferns (Sagenopteris, Pachypteris), bennettitaleans, cycads (Nilssonia) and conifers (Podozamites,

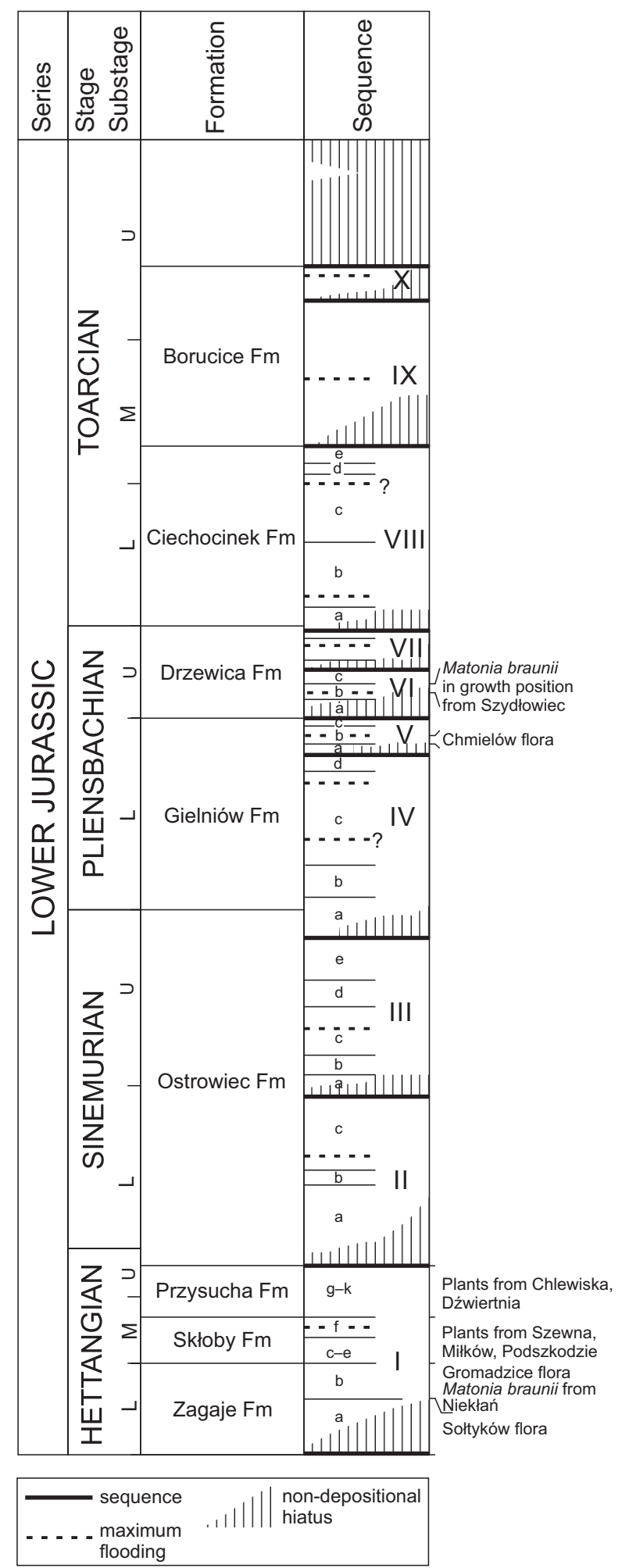

Fig. 2. Stratigraphy of the Lower Jurassic deposits of the Holy Cross Mountains (after Pieńkowski 2004: figs 3 and 72, modified), with source strata of the investigated material and other discussed fossil floras. Abbreviations used: L - lower, $\mathrm{M}$ - middle, $\mathrm{U}$ - upper

Brachyphyllum, Pityophyllum, Stachyotaxus) are rare. In contrast to the floral remains gathered recently from the lower outcrop in Gromadzice, Raciborski's collection is ferndominated. The plant fossils originated from 
two different sediment types: fine clay probably of lacustrine origin, and sandy mudstone of fluvial origin. In sandy mudstones the ferns are numerous: Dictyophyllum spp., Marattiopsis muensteri, Thaumatopteris brauniana and several specimens of pinnae fragments and isolated pinnules of Phlebopteris angustiloba and pinnae fragments of Matonia braunii. Also present are the sphenopsids Neocalamites lehmannianus and Equisetites muensteri, and the gymnosperms Sagenopteris sp., Ixostrobus siemiradzkii, Taeniopteris tenuinervis, Schizolepis follinii and Stachyotaxus septentrionalis. Fossils are much rarer in fine clays, but one specimen of Phlebopteris angustiloba pinnae and an isolated pinnule of Matonia braunii with sori preserved were found.

\section{MATERIALS AND METHODS}

For this research, all available historical specimens of Matoniaceae from Lower Jurassic strata of the Holy Cross Mountains deposited in the Geological Museum of the Institute of Geological Sciences, Polish Academy of Sciences Research Centre in Cracow (formerly the collection of the Physiographical Commission of the Polish Academy of Arts and Sciences), were studied. These specimens were published only in part by Raciborski (1891, 1892) and Makarewiczówna (1928). They are stored under collection numbers ZNG PAN A-III-25 and 26 . It should be mentioned that collection and specimen numbers were assigned to these specimens many years after Raciborski's work; he did not use a system of numbering for his hand specimens. This caused problems in identifying which specimens had been described and illustrated; sometimes identification is impossible. For specimens determined to have been illustrated by Raciborski, the original plate and figure numbers are given in parentheses after the collection acronym and specimen number. The shape of the stone slabs of some drawn specimens differs considerably from the reality. Some specimens were cropped for better alignment of the plate, and other drawings show the front and back of the specimen together in one plane. Another problem is that some specimens were wrongly assigned to source localities, even by Raciborski himself and probably also later by collection curators. Based on the lithology and the taxa preserved, it is evident that some specimens from Gromadzice were assigned to the Chmielów and even the Grojec localities (e.g. A-III-12/208), and vice versa. The following specimens that are revised here were undoubtedly examined by Raciborski and described in his papers: A-III-26/2, 4a+b, 20-21, 33-36, 48 (Raciborski, 1891, 1892). Some specimens identified by Raciborski as belonging to Laccopteris elegans (A-III26/32-33) do not belong to Matoniaceae but probably to Osmundaceae. Specimens A-III-25/24-32, and PC IB UJ 106/54a+b have not been examined earlier. Raciborski's historical plant fossil remains from Lower Jurassic strata of the Holy Cross Mountains (belonging to the
Institute of Botany, Jagiellonian University) have also been examined; no matoniaceous fern was identified, however. In a large recently gathered collection of fossil plants from Gromadzice, only one specimen (positive and negative) belongs to the Matoniaceae. This collection is stored in the Institute of Botany, Jagiellonian University, collection number Palaeobotanical Collection IB UJ 106.

The specimens are preserved as impressions, sometimes with remnants of coaly matter (A-III-25/31, PC IB UJ 106/54a). Details of sori and sporangia are rare and poorly preserved. The specimens are very difficult to photograph due to the lack of contrast and the faintness of three-dimensional relief. The condition of the historical specimens is not good; they are heavily dusted. Many crucial details of, for example, sori and sporangia structure, which Raciborski observed, described and illustrated, are not visible today at all, probably due to small damages incurred during long storage. This hampers revision and reinterpretation of some important specimens. Important morphological details are more visible on recently discovered specimens. The plant remains were observed with a Technival 2 stereoscopic microscope and photographed with a Nikon NIKKOR AF-s DX Micro NIKKOR $85 \mathrm{~mm}$ f/3.5G ED VR camera. Polarised light was used to increase the contrast.

The suprageneric classification follows Cronquist et al. (1966), Smith et al. (2006) and PPG I (2016).

\section{SYSTEMATIC DESCRIPTION}

\author{
Class: POLYPODIOPSIDA Cronquist, \\ Takhtajan et Zimmermann, 1966
}

Order: GLEICHENIALES Schimper, 1869

Family: MATONIACEAE Presl, 1848

Genus: Matonia R. Brown in Wallich, 1830

\section{Matonia braunii}

(Goeppert, 1841) Harris, 1980

$$
\text { Pl. 1, figs 1-5a }
$$

\section{Selected synonyms:}

1841 Laccopteris brauni Goeppert; Goeppert, pp. 7, 8, pl. 5, figs 1-7.

1841 Laccopteris germinans Goeppert; Goeppert, pp. 9, 10, pl. 6, figs 1-12.

1865-1867 Laccopteris göpperti Schenk; Schenk, pp. 94-97, pl. 23, figs 1-12, pl. 24, figs 2-5.

1865-1867 Laccopteris münsteri Schenk; Schenk, pp. 97, 98, pl. 24, figs $6-10$, pl. 25, figs 1, 2a, b.

non 1891 Laccopteris elegans Presl in Sternberg; Raciborski, pp. 305, 306, pl. 4, figs 1, 4.

1899 Laccopteris elegans Presl in Sternberg; Seward, pp. 193-196, text-fig. 8.

1926 Laccopteris groenlandica Harris; Harris, pp. 62-64, pl. 3, fig. 5, text-fig. 6 . 
? 1928 Laccopteris elegans Presl in Sternberg; Makarewiczówna, p. 3.

1928 Laccopteris Münsteri Schenk; Makarewiczówna, p. 4, p. 1(10), figs 2, $2 \mathrm{a}$.

1931 Laccopteris brauni Goeppert; Harris, pp. 70-74, pl. 14, figs 1, 2, pl. 15, fig. 7, text-figs 24, 25 .

1936 Phlebopteris brauni (Goeppert) Hirmer and Hoerhammer; Hirmer and Hoerhammer, pp. 7-17, text-figs $3,4,5,1 \mathrm{~A}-1 \mathrm{D}$, pl. 1, figs $1-12$, pl. 2, figs $1-4$, pl. 4, fig. 7 .

1936 Phlebopteris muensteri (Schenk) Hirmer et Hoerhammer; Hirmer et Hoerhammer, pp. 17-26, text-figs B, 5, 2A-2B, pl. 3, figs 1-7, pl. 4, figs $1-6$, pl. 5, figs 1-6.

1980 Matonia braunii (Goeppert) Harris; Harris, pp. 295-310, figs 1-20.

1997 Matonia braunii (Goeppert) Harris; Popa, p. 142, text-figs 19, 20, pl. 2, fig. 5 .

2016 Matonia braunii (Goeppert) Harris; Barbacka et al., pp. 860-865, figs 2-5.

2019 Matonia braunii (Goeppert) Harris; Barbacka et al., pp. 167-169, figs 6h, 7a, b.

2020 Phlebopteris muensteri (Schenk) Hirmer et Hoerhammer; Van Konijnenburg-van Cittert et al., pp. 9-11, pl. 5, figs 1-6.

Material. Pinnae fragments: A-III-25/28, 30, 32 (all sterile), PC IB UJ 106/54a+b (fertile); isolated fertile pinnule: A-III-25/31. All specimens from Gromadzice, uppermost part of Zagaje Formation, parasequence Ib, lower Hettangian.

Description. Only fragments of apical parts of sterile and fertile pinnae preserved, 7-65 mm long (Pl. 1, figs 1-5). Pinnae rachis 0.5-1.5 $\mathrm{mm}$ wide. Pinnae once pinnate, size of pinnules slightly decreasing towards pinna apex. Most pinnules incomplete, lacking apices, preserved length $15-18 \mathrm{~mm}$. Pinnules $2.0-3.5 \mathrm{~mm}$ wide at base, towards apex slightly narrowing to $1.5-3.0 \mathrm{~mm}$. Pinnules with straight margins, densely arranged, attached at $\sim 80^{\circ}$ angle, subopposite. Adjacent pinnules $0.5-1.5 \mathrm{~mm}$ apart, connected through gentle narrow wing, up to 0.5 wide along rachis. Pinnule venation difficult to recognise, only central vein visible ( $\mathrm{Pl}$. 1, figs 1-5). On fertile pinnules, rows of sori on both sides of central vein, occupying almost full width of pinnule lamina between vein and margin (Pl. 1, figs 1, 2, 5). Sori $0.7-1.0 \mathrm{~mm}$ in diameter, $0.2-0.5 \mathrm{~mm}$ apart (Pl. 1, figs 1a, 5). At least six sporangia per sorus. Sporangia oval, $0.1-0.2 \mathrm{~mm}$ in diameter with prominent annuli (Pl. 1, figs 1b, 5a).

Remarks. The material documented here is compatible with that described and illustrated by Harris (1980) and Barbacka et al.
(2016, 2019) as Matonia braunii and by Goeppert (1841), Schenk (1865-1867), Seward (1899), Harris (1931), Hirmer and Hoerhammer (1936) and Van Konijnenburg-van Cittert et al. (2020) as belonging to Phlebopteris braunii and Phlebopteris muensteri. Harris (1980) interpreted these two latter species to be synonymous, considering the specimens classified as Phlebopteris muensteri to be sun fronds and Phlebopteris braunii to be shade fronds of the same species. Historically, most authors have referred mainly sterile leaves with rather short, even somewhat triangular pinnules to Phlebopteris braunii, and mainly fertile leaves with rather long linear pinnules to Phlebopteris muensteri (see e.g. Hirmer and Hoerhammer, 1936 for a very good illustration of this). However, intermediate specimens prevail or both morphologies co-occur in many published collections (e.g. Barbacka et al., 2016; Van Konijnenburg-van Cittert et al., 2020), and clear morphological differences on which separation on these species may be based are lacking. Harris (1980) also confirmed the presence of indusiate sori in his material, and on this basis referred both these species to the extant genus Matonia and combined them under the name Matonia braunii (Goeppert) Harris. This opinion is maintained here, though it should be mentioned that some authors still question their synonymy (see e.g., Van Konijnenburgvan Cittert, 1993; Schweitzer et al., 2009; Van Konijnenburg-van Cittert et al., 2020), based on elusive differences in leaf and sori morphology. According to these authors the most important difference between these species is the presence of indusiate sori in Matonia (Phlebopteris) braunii and their lack in Phlebopteris muensteri. This is in accordance with Hirmer and Hoerhammer's (1936) hypothesis that the oldest members of Matoniaceae (included in the genus Phlebopteris) are exindusiate and that the indusium evolved gradually in this family during the Mesozoic. However, both these species (exindusiate and indusiate) co-occur even in their oldest Upper Triassic records, and Klavins et al. (2004) documented indusiate sori in the oldest known Matoniaceae from the Middle Triassic of Antarctica. So even if Hirmer and Hoerhammer's (1936) hypothesis of the indusium's origin in Matoniaceae is correct, it cannot be documented based on available Mesozoic fossils, and this evolutionary change must have taken place before the first 

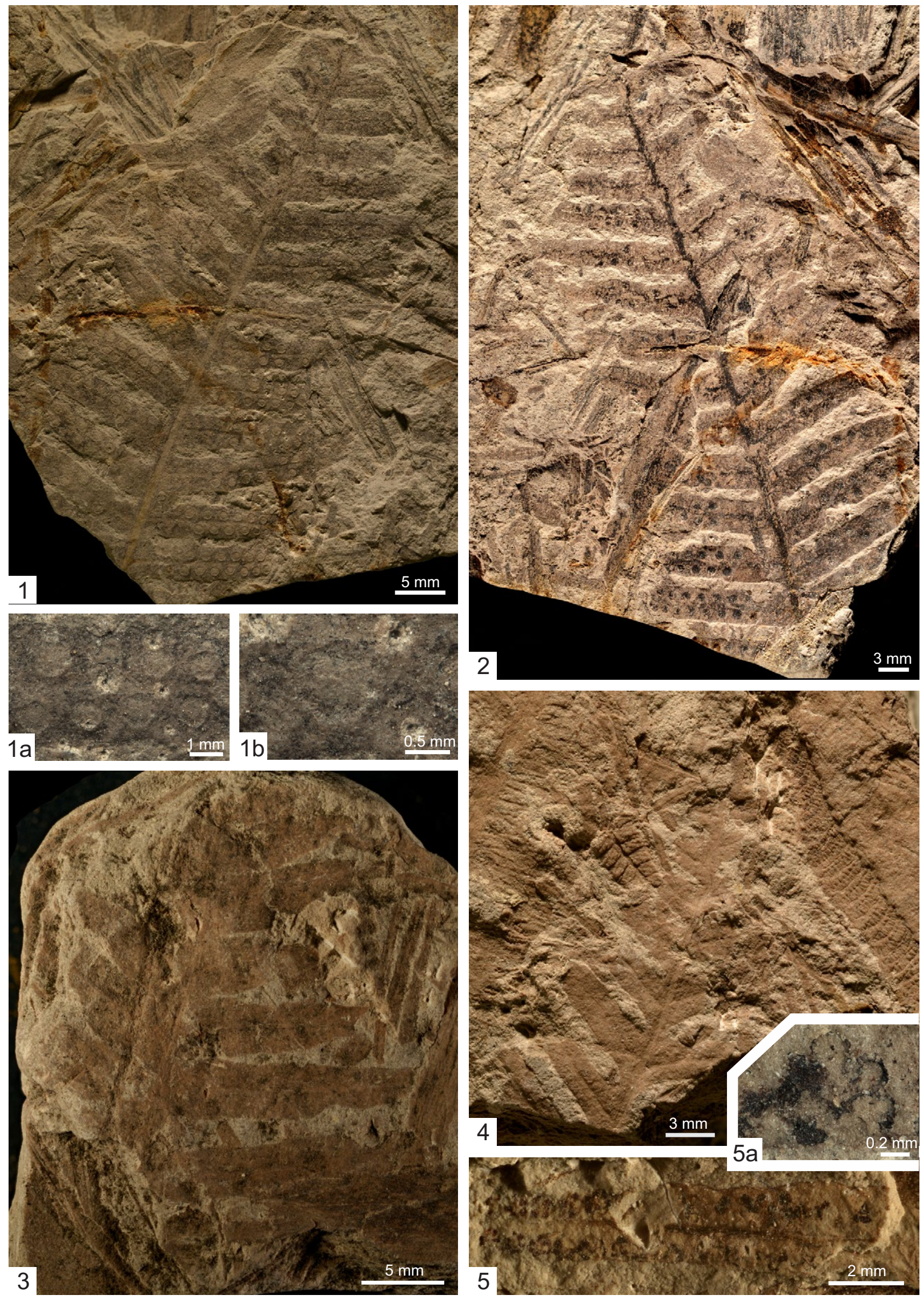

Plate 1. Matonia braunii. 1. Fertile pinna, positive, PC IB UJ 106/54a; 1a. Detail from 1, fragment of pinnule with sori visible, needle marks after preparation visible between sori; 1b. Detail from 1a, one sorus, faint imprints of sporangia with annuli visible; 2. Fertile pinna, negative, PC IB UJ 106/54b; 3. Fragment of sterile pinna, A-III-25/30; 4. Apical part of small sterile pinna, A-III25/28; 5. Isolated fertile pinnule, sori with sporangia visible, A-III-25/31; 5a. Detail from 5 , one sorus, sporangia with annuli visible 
appearance of indusiate Matoniaceae in the Middle Triassic (Klavins et al., 2004).

The following features of this material confirm that it belongs to Matonia braunii as interpreted by Harris (1980) and Barbacka et al. (2016, 2019): pinnae shape, pinnule shape and dimensions, type of venation, size, and sori shape and arrangement. The specimens described here are in the middle range of variability limited by the morphotype margins described as the separate species Phlebopteris braunii and Phlebopteris muensteri. They have pinnules shorter and wider than most typical specimens referred historically to $P$. muensteri, and pinnule size decreasing lengthwise towards the pinna apex, which is most typical for specimens referred to $P$. braunii. Only naked sori without indusia were observed ( $\mathrm{Pl}$. 1, figs $1 \mathrm{~b}, 5 \mathrm{a})$. The indusia probably were lost before pinnae fossilisation, as the sporangia are well developed and hence probably mature and ready to disperse spores. This interpretation is based on Harris's (1980) careful observations of recent Matonia. In mature leaves the indusia are easily lost, revealing sporangia ready to disperse spores. The well-known Late Triassic species Phlebopteris smithii (Daugherty) Arnold was described as exindusiate, but the authors (Arnold, 1956; Ash et al., 1982; Litwin, 1985) could not exclude the possibility that indusia were present during the leaves' early ontogenetic stages, since they have at their disposal only mature fertile leaves with well-developed sporangia. New well-preserved material of Matonia braunii from the Niekłań borehole in the Holy Cross Mountains described by Barbacka et al. (2016) is also important for several reasons in the present context. First, it confirms Harris's (1980) suggestion that Phlebopteris braunii and Phlebopteris muensteri are conspecific based on their co-occurrence and indusiate sori details. The Niekłań material has well-visible indusia, which also concurs with Harris's referral of Phlebopteris braunii to the recent genus Matonia. Second, pinnules with morphology typical for P. muensteri have indusia preserved (Barbacka et al., 2016: figs 3E-G), a feature not observed before (compare Van Konijnenburg-van Cittert, 1993). In the sori of some mature pinnules from Niekłań not only are the indusia lost but even part of the sporangia fell off. This is also in line with Harris's neontological observations (Harris, 1980).
Specimens from Poland that may belong to Matonia braunii were first mentioned by Raciborski (1891) and referred to Laccopteris elegans. During the present research and after an examination of the original specimens, it appeared that the two biggest specimens thoroughly described and illustrated by Raciborski (1891: pl. 4, fig. 1, 4, specimens A-III-26/32, 33) as Laccopteris elegans cannot not be referred to this poorly defined species, other Phlebopteris species, or even the family Matoniaceae. Those specimens, although poorly preserved and difficult to examine, show some important features incompatible with this family. Pinnule size changes gradually on most Phlebopteris or Matonia pinnae, but here they almost do not change along the pinna rachis. The pinnules in these specimens are not oblong as is typical for Matoniaceae, but rather somewhat triangular (especially in specimen A-III-26/33); however, this feature is not so prominent as in the genus Cladophlebis. The venation is of neuropterid type rather than pecopterid or pecopterid-reticulate as in Phlebopteris. These specimens may belong to Osmundaceae and will be the subject of forthcoming research to be published later.

The species Laccopteris elegans was proposed by Presl in Sternberg (1838), based on poorly preserved isolated pinnules. Actually the type specimen has only one pinnule preserved (Hirmer and Hoerhammer, 1936; Jung and Knobloch, 1972; Kvaček and Straková, 1997). However, before the last part of Sternberg's work was printed, Goeppert (1836) described and identified the same specimen as Asterocarpus lanceolatus Sternberg (proper species authorship should be Asterocarpus lanceolatus Sternberg in Goeppert). He did not publish an illustration himself, but referred to a plate in Sternberg's work, with an error (plate 31 instead of plate 32 ). Therefore the species name Laccopteris elegans is a nomenclatural synonym of Asterocarpus lanceolatus and an illegitimate name as superfluous, including the type of the formerly validly published name (Turland et al., 2018). Moreover, the type Laccopteris elegans is indeterminate and may not even belong to Matoniaceae (Hirmer and Hoerhammer, 1936). Laccopteris elegans Presl in Sternberg was treated for some time by many authors including Raciborski himself (Schimper, 1869-1874; Raciborski, 1891; Seward, 1899; Möller, 1902; Lilpop and Kostyniuk, 1957) as a synonym of Phlebopteris braunii. 
Although the specimens described and illustrated by Raciborski (1891) were misidentified, historical specimens available to him but not described in his publication confirm the presence of Matonia braunii (=Phlebopteris braunii) in Gromadzice. These specimens are documented in the present paper for the first time, along with new material of that species from this locality. In fact, Raciborski (1981) mentioned along with two illustrated specimens the presence of other incomplete and worse-preserved specimens but did not describe them; perhaps he meant some specimens described here. Some specimens Raciborski described and illustrated are no longer in his collection. Among these lost specimens is one that may belong to Matonia braunii; it was figured on pl. 2, fig. 14 in Raciborski (1892). It is referred to in the text (p. 349) as Dictyophyllum aff. dunkeri, as Thaumatopteris dunkeri in the plate explanation, and as Dictyophyllum dunkeri in the plate caption. The shape of the pinnae and pinnules, their prominent central vein and the lack of mesh venation are congruent with the determination proposed here.

Occurrence. Matonia braunii as understood here (Phlebopteris braunii and P. muensteri as its synonyms) is known from the Late Triassic to Early Cretaceous, mainly from Europe, most frequent and characteristic for the Early Jurassic. The best-preserved and the most numerous specimens were found in Lower Jurassic strata of Germany (Goeppert, 1841; Schenk, 18651867; Van Konijnenburg-van Cittert, 1993; Van Konijnenburg-van Cittert et al., 2020), Greenland (Harris, 1926, 1931), Sweden (Möller, 1902) and Romania (Popa, 1997) and in Middle Jurassic strata of England (Harris, 1961, 1980). In Polish Early Jurassic floras this species is a characteristic but not very numerous element (Pacyna, 2013, 2021; Barbacka et al., 2014, 2016). Raciborski (1891) wrote that the species Laccopteris elegans (which he treated as a synonym of $P$. braunii) is rather frequent in Gromadzice and rarer in Chmielów. In the revised collections only specimens from Gromadzice were found. Specimens documented here confirm the presence of Matonia braunii (=Phlebopteris braunii) in this locality. Makarewiczówna (1928) listed Laccopteris elegans from Gromadzice, Szewna and Jędrzejowice, but because she did not illustrate any specimen, her determinations were based on Raciborski (1891), and the specimens were lost, this record cannot be checked. One illustrated fertile specimen from Chmielów which she determined as Laccopteris Münsteri most probably belongs to Matonia braunii. Specimens collected and listed by Kuźniar (1923, 1924) as Laccopteris elegans and revised by Lilpop and Kostyniuk (1957) as Phlebopteris braunii from Chlewiska near Szydłowiec probably were lost during World War II. This record is based on determinations alone, without any description or illustration, and its source locality is unavailable today, so it is not possible to verify the determination. A specimen probably referable to Matonia braunii was described by Barbacka et al. (2014) from strata of Toarcian-Aalenian age from the Ciechocinek IG 1 borehole as Phlebopteris muensteri. New well-preserved fertile and sterile material of Matonia braunii was described by Barbacka et al. (2016) from the Niekłań borehole in the Holy Cross Mountains. Pacyna (2021) recently described this fern preserved in the growth position from Upper Pliensbachian strata of the Drzewica Formation in Szydłowiec.

Genus: Phlebopteris Brongniart, 1829

\section{Phlebopteris angustiloba}

(Presl in Sternberg, 1838)

Hirmer and Hoerhammer, 1936

Pl. 2, figs 1-6, Pl. 3, figs 1-6

\section{Selected synonyms:}

1838 Gutbiera angustiloba Presl in Sternberg; Presl in Sternberg, p. 116, pl. 33, figs 13a-e.

1843 Andriania baruthina Braun; Braun, pp. 42-46, pl. 9, figs 3-12, pl. 10, figs 1-4.

1865-1867 Gutbiera angustiloba Presl in Sternberg; Schenk, pp. 64-66, pl. 18, figs 5-10.

1865-1867 Andriana baruthina Braun; Schenk, pp. 87-89, pl. 21, figs 1-8, pl. 24, fig. 1.

1891 Laccopteris angustiloba (Presl in Sternberg) Raciborski; Raciborski, pp. 306-308, pl. 2, figs 6-9, pl. 3, figs 1-3.

1892 Laccopteris angustiloba (Presl in Sternberg) Raciborski; Raciborski, pl. 2, fig. 22.

1914 Gutbiera angustiloba Presl in Sternberg; Gothan, pp. 99-100, pl. 17, fig. 5.

1914 Andriana baruthina Braun; Gothan, p. 102, pl. 17, fig. 8, pl. 18, figs 1,2 .

1914 Andriana norimbergica Gothan; Gothan, pp. 102, 103, pl. 17, figs 6, 7 .

1931 Laccopteris angustiloba (Presl in Sternberg) Raciborski; Harris, pp. 74-77, pl. 14, figs 6-17, text-fig. 26.

1936 Phlebopteris angustiloba (Presl in Sternberg); 
Hirmer and Hoerhammer, pp. 26-33, pl. 6, figs 1-4, text-fig. 5, 3 .

1950 Phlebopteris angustiloba (Presl in Sternberg) Hirmer et Hoerhammer; Lundblad, pp. 23, 24, pl. 2, fig. 14; pl. 3, figs 1-5, pl. 13, fig. 2, text-fig. 4 .

1965 Phlebopteris angustiloba (Presl in Sternberg) Hirmer et Hoerhammer; Tralau, pp. 373-376, figs $1 \mathrm{a}-\mathrm{d}$.

1993 Phlebopteris angustiloba (Presl in Sternberg) Hirmer et Hoerhammer; Van Konijnenburg-van Cittert, pp. 241-243, pl. 1, figs 2, 5.

1997 Phlebopteris angustiloba (Presl in Sternberg) Hirmer et Hoerhammer; Popa, p. 142, textfig. 13.

2019 Phlebopteris angustiloba (Presl in Sternberg) Hirmer et Hoerhammer; Barbacka et al., pp. 161-163, figs 4f, g, 5a, b.

2020 Phlebopteris angustiloba (Presl in Sternberg) Hirmer et Hoerhammer; Van Konijnenburg-van Cittert et al., p. 9, pl. 4, figs 4-6.

Material. Pinnae fragments: A-III-25/24, 25, 26, 27, A-III-26/2 (Raciborski, 1891: pl. 1, fig. 2b), 21 (Raciborski, 1892: pl. 2, fig. 22), 34 (Raciborski, 1891: pl. 2, fig. 8), 35 (probably Raciborski, 1891: pl. 2, fig. 9), 36; isolated pinnules: A-III12-208, A-III-25/28 (sterile), 29, A-III-26/4a+b, 20 (Raciborski, 1891: pl. 4, fig. 2), 33, 48, numerous isolated pinnules on so-far uncatalogued specimens. All specimens probably from Gromadzice based on sample lithology and co-occurring taxa, on some specimen labels erroneously Miłków (A-III-25/25, 26, A-III-26/36), Chmielów (A-III-26/20, 48) and Grojec (A-III-12/208). All specimens fertile except when indicated as sterile. Lower Hettangian, upper part of Zagaje Formation, parasequence Ib.

Description. Only fragments of pinnae and numerous isolated pinnules preserved (Pl. 2, figs 1-6, Pl. 3, figs 1-6). All pinnae fragments fertile, 30-60 mm long (Pl. 2, figs 1-6, Pl. 3, figs $1-2)$. Pinnae rachis $0.3-0.8 \mathrm{~mm}$ wide. Isolated pinnules are both fertile and sterile (Pl. 3, figs 2-6). Pinnae once-pinnate, most pinnules incomplete, lacking apices (Pl. 2, figs 4-6), preserved length 18-30 mm. Pinnules linear, 1.8$3.5 \mathrm{~mm}$ wide, very slightly narrowing towards apices, densely arranged, touching each other, attached at $80^{\circ}-85^{\circ}$ angles, positioned slightly suboppositely, somewhat falcate towards pinna apex. Main pinnule vein gives rise to lateral secondary veins almost perpendicularly, producing a mesh consisting of rectangular to roundish depressions (if specimen preserved as negative, $\mathrm{Pl}$. 1, figs 2, 3; Pl. 3, figs 1, 2), 0.9-1.4 mm wide (measured perpendicularly to main pinnule vein) and 0.5-1.0 long (measured along pinnule length). These rectangular units represent the areas where sori were attached but the details of sori and sporangia generally are not preserved. Very faint remains of sori with sporangia possibly present only on specimen A-III-26/34 (Pl. 2, figs, 1, 1a); they may be consistent with Raciborski's figure (1891: pl. 3, figs 1-3) in having at least four sporangia and an annulus consisting of cells smaller than in Matonia braunii (Pl. 2, fig. 1a). In specimen A-III-26/36, most basal rectangular units of pinnules adhering to pinnae rachis are prominent and slightly larger, $1.2 \mathrm{~mm}$ wide, $1.5 \mathrm{~mm}$ long (Pl. 2, fig. 2). Rectangular units distinctively convex on fertile fronds if pinnule preserved as positive (Pl. 2, figs 5, 6), sometimes with small hollow pit in centre, commonly interpreted as a receptacle, or maybe a trace of an indusium stalk if this species was indusiate (Pl. 2, fig. 5; Pl. 3, fig. 3). Rectangular units only slightly convex on sterile pinnules, also somewhat larger, $1.5 \mathrm{~mm}$ wide, $1.0 \mathrm{~mm}$ long (specimen A-III-25/28, Pl. 3, fig. 5). Higherorder venation visible on sterile pinnule, secondary veins branch nearly parallel to midrib and subsequently 2-3 times diagonally within the unit (Pl. 3, fig. 5).

Remarks. The species Phlebopteris angustiloba (Presl in Sternberg, 1838) Hirmer and Hoerhammer, 1936 was proposed by Presl as Gutbiera angustiloba (Presl in Sternberg, 18201838) based on reasonably good fertile material. Very similar specimens were described later under several names. Braun (1843) described numerous fertile and probably also sterile specimens under the binomen Andriana baruthina Braun, 1843. He described and illustrated a large frond fragment and numerous isolated pinnae, and documented details of sori and pinnule venation. In Schenk (1865-1867), material referrable to $P$. angustiloba was described under both earlier-proposed names; he treated these as separate species. However, in 1888 he suggested that these two species might be synonymous. Only Raciborski (1891) formally synonymised these species, describing the specimens revised here. He assigned them to the genus Laccopteris as Laccopteris angustiloba (Presl in Sternberg, 1838) Raciborski, 1891. The genus Laccopteris Presl in Sternberg, 1838 (Sternberg, 1820-1838) is a heterotypic synonym (taxonomic synonym) of Phlebopteris Brongniart, 1829 (Brongniart, 1828-1837) so 

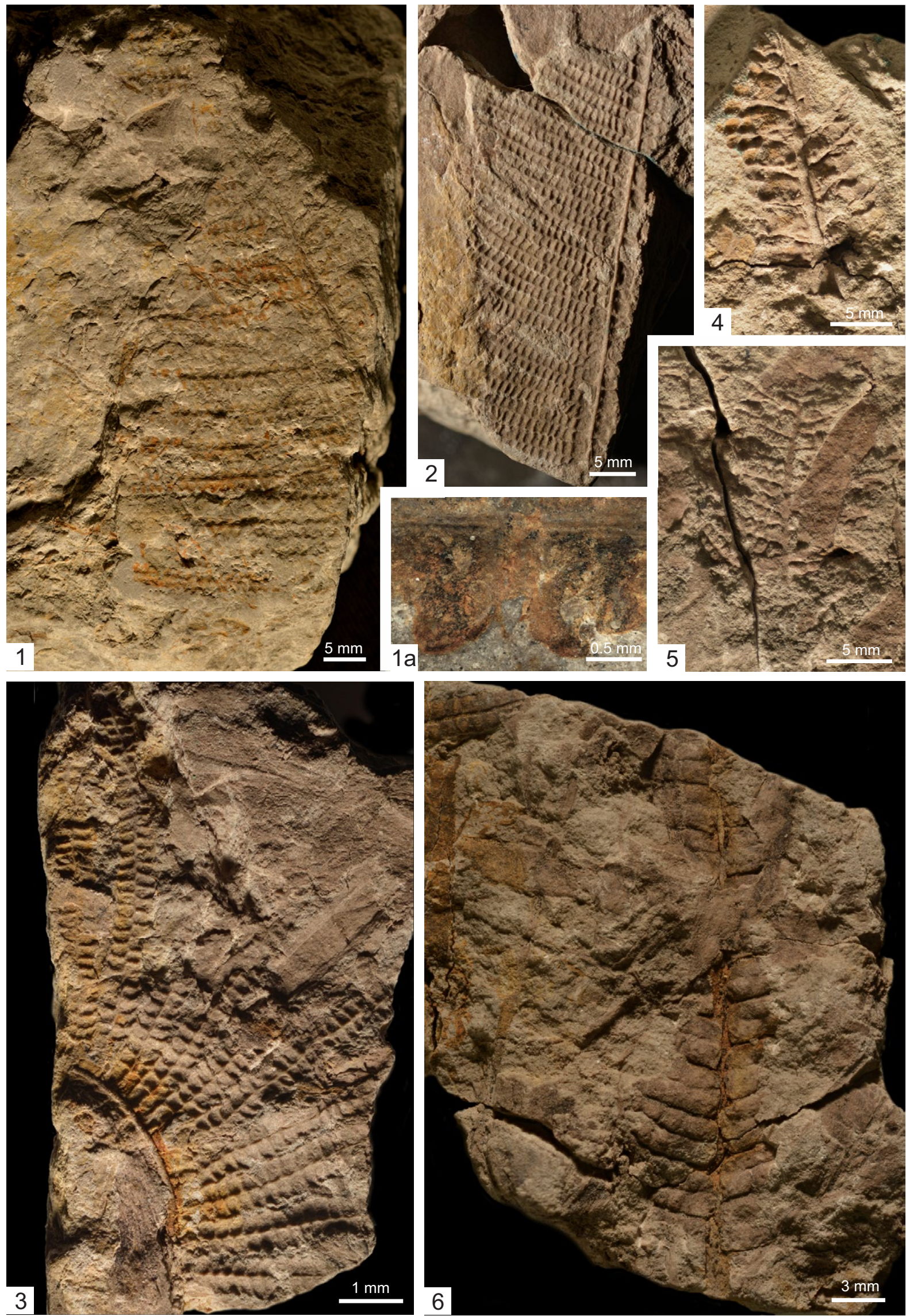

Plate 2. Phlebopteris angustiloba. 1. Fragment of fertile pinna, A-III-26/34; 1a. Detail from 1, pinnule fragment, margin damaged, sori and their details hardly visible; $\mathbf{2}$. Fragment of fertile pinna, most basal rectangular units of pinnules adhering to pinna rachis, prominent and slightly larger, A-III-26/36; 3. Fragment of arched fertile pinnule, A-III-25/21; 4. Fragment of fertile pinna, pinnules incomplete, lacking apices, A-III-25/25; 5. Fragment of fertile pinna, A-III-25/26; 6. Fragment of fertile pinna, A-III-25/27 

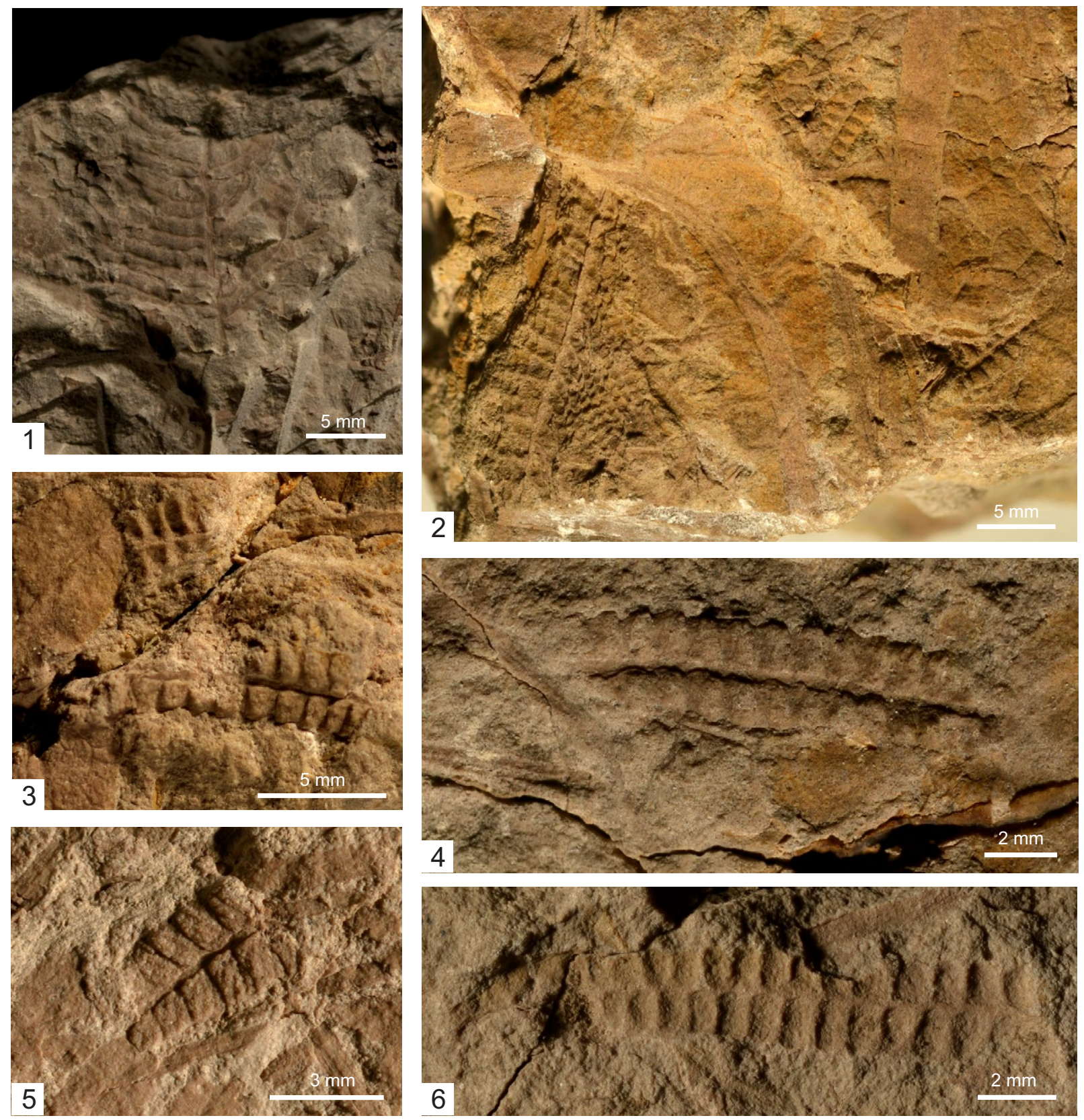

Plate 3. Phlebopteris angustiloba. 1. Fragment of fertile pinna, A-III-26/2; 2. Fragments of deformed fertile pinna and three isolated fertile pinnules with incomplete fragment of Dictyophyllum sp., A-III-25/24; 3. Two fragments of isolated fertile pinnules, upper negative, lower positive with small hollow pits in centre of sori, A-III-26/20; 4. Positive fragment of fertile pinnule, A-III-26/33; 5. Fragment of sterile pinnule with venation visible, A-III-25/28; 6. Negative fragment of fertile pinnule, A-III-12/208

Hirmer and Hoerhammer (1936) correctly proposed the currently accepted name.

The Polish material is very similar to specimens described by Presl in Sternberg (1838), Braun (1834), Hirmer et Hoerhammer (1936), Tralau (1965), Lundblad (1950), Barbacka et al. (2019) and Van Konijnenburg-van Cittert et al. (2020) in size, the shape of the pinnules and especially the mattress-like appearance of the pinnules. Recently, Barbacka et al. (2019) described and illustrated well-preserved material of this species from the Hettangian of Hungary, illustrating details of the pinnule venation and sori. The here-revised material is not so well preserved but details of sterile pinnule venation were observed (Pl. 3, fig. 5). Raciborski (1981) described and illustrated (with drawings) details of the sori and sporangia based on this material. During the recent research it was not possible to confirm his observations. Raciborski (1891) did not indicate which specimen he used for his detailed observations. It could be specimen A-III-26/34, which Raciborski thoroughly described in the text and on which some remains of sori are still traceable today. Unfortunately, the details visible today (Pl. 2, figs, 1 , 
1a) are definitely worse than in his illustration. He mentioned that this specimen was damaged during transport, and damage is in fact visible on this specimen, so it cannot be ruled out that better details were visible before abrasion. Fertile specimens are numerically dominant in the revised material but there is also a sterile specimen (Pl. 3, fig. 5), though it was not recognised as such by Raciborski (1891). The sterile pinnule is compatible with those described by Antevs (1919), Harris (1931) and Barbacka et al. (2019). It has rectangular units less convex than in fertile pinnules, and third-order venation well visible.

This species is commonly considered to be exindusiate, like the whole genus Phlebopteris, but Harris (1980) convincingly showed that Phlebopteris braunii (and synonymised with it Phlebopteris muensteri, together named Matonia braunii) occasionally had an indusium, which was easily lost, as in modern Matonia. He described and illustrated both specimens with an indusium still in place, and specimens in which the indusium was lost so that sporangia were visible. This observation was confirmed by Barbacka et al. (2016) based on specimens from Niekłań. Specimens of Matonia braunii with indusia still in place have sori visible as bulges with a small hollow pit in the centre. Some specimens of $P$. angustiloba described here are preserved in that way ( $\mathrm{Pl}$. 3, fig. 3), and similar ones were earlier illustrated by Antevs (1919: pl. 1, fig. 9a). That sori with visible sporangia may be preserved in this species is confirmed by, for example, the specimen illustrated by Barbacka et al. (2019, fig. 5b). If an indusium was present in this Phlebopteris species, it can only be demonstrated by further research based on very well-preserved specimens. If it turns out that Phlebopteris as a whole is indeed indusiate, this will have far-reaching taxonomic consequences. The state of preservation of the present material is not good enough to settle this question for $P$. angustiloba. It is worth adding that the same mode of preservation of sori (bulges with a pit in the centre) is typical for Matonidium goepperti, which is considered to be indusiate (Harris 1961 and author's own observations based on Middle Jurassic Grojec material).

Occurrence. This species is characteristic for Rhaetian-Hettangian floras, predominantly distributed in Lower Jurassic strata of Europe, including Greenland (Harris, 1931), Sweden
(Antevs, 1919; Lundblad, 1950; Tralau, 1965), Denmark (Möller, 1902), Germany (Braun, 1843; Schenk, 1865-1867; Gothan, 1914; Weber, 1968; Van Konijnenburg-van Cittert et al., 2020), Hungary (Barbacka et al., 2019) and Romania (Popa, 1997). In Poland, Raciborski (1891) wrote that this species is common in Gromadzice but rare in Chmielów. Since some historical specimens from Gromadzice were wrongly attributed to Chmielów, based on the specimens available today the occurrence of this species in Chmielów cannot be confirmed. Makarewiczówna (1928) listed this species as Gutbiera angustiloba from Gromadzice and Chmielów. Her specimens from the collection of the Institute of Botany, Jagiellonian University, are lost. This species is moderately frequent in the slightly older early Hettangian flora of Sołtyków (Odrowąż) but represented only by isolated pinnules (Barbacka et al., 2010).

\section{CONCLUSIONS}

All available published and unpublished historical specimens (20 items) and some new material (one specimen preserved as positive and negative) of Matoniaceae ferns from Lower Jurassic strata of the Holy Cross Mountains were revised according to current views of the taxonomy of Mesozoic members of this family. The presence of Matonia brauni in the Hettangian of the Holy Cross Mountains was confirmed based on historical and newly collected specimens. This fern is a rather rare element in the flora. In contrast, Phlebopteris angustiloba is rather frequent, especially as isolated pinnules. However, the state of preservation of all available specimens prevents confirmation of Raciborski's (1891) observations about the sori and sporangial structure in this species. A sterile specimen has well-visible venation preserved, but this was not documented by Raciborski. Two large specimens illustrated by Raciborski (1891) and determined as Laccopteris elegans do not belong to Matoniaceae but probably to Osmundaceae. Only some specimens of $P$. angustiloba illustrated by Raciborski could be traced with certainty in the preserved collection. Some specimens historically referred to the Matoniaceae from the Holy Cross Mountains could not be revised based on illustrations alone, because they never were described and illustrated properly 
and the specimens are lost. The reliability of historical labels in collections published by Raciborski, especially with regard to the origin of the specimens, must be treated with caution. Also, after long storage of the specimens (more than a century) some subtle morphological and anatomical details may have been lost.

\section{ACKNOWLEDGEMENTS}

I am grateful D. Zdebska (Institute of Botany, Jagiellonian University, Cracow), M. Barbacka and especially J. Ziaja (W. Szafer Institute of Botany, Polish Academy of Sciences, Cracow) for help and discussions, G. Pieńkowski (Polish Geological Institute - National Research Institute, Warsaw) for taking me to the outcrop in Gromadzice and for discussions about the geological context and age of Early Jurassic floras of the Holy Cross Mountains, M. Szewczyk and K. Stachowicz for photos of the specimens, A. Sojka for preparing the figures, and the journal referees Johanna H.A. van Konijnenburg-van Cittert (Naturalis Biodiversity Center, Leiden and Laboratory of Palaeobotany and Palynology, Utrecht, the Netherlands) and Emese R. Bodor (Eötvös Loránd University, Budapest, Hungary) for their helpful comments and suggestions. Special thanks for the curators of the palaeobotanical collections in the Geological Museum of the Institute of Geological Sciences, Polish Academy of Sciences, Research Centre in Cracow, Agata Jarzynka and Barbara KietlińskaMichalik (ret.), for the loan of Raciborski's specimens, access to comparative collections, and their hospitability and help during research. The study was financed by funds from the National Science Centre, Poland (grant no. 2017/25/B/ST10/01273) and the Institute of Botany of the Jagiellonian University (N18/DBS/000002).

\section{REFERENCES}

Antevs, E., 1919. Die Liassische Flora des Hörsandsteins. Kungliga Svenska Vetenskapsakademiens Handlingar 59(8), 1-71. https://doi. org/10.1080/11035891909443882

Arnold, C.A., 1956. Fossil ferns of the Matoniaceae from North America. Journal of the Palaeontological Society of India 1, 118-121.

Ash, S., Litwin, R.L., Traverse, A., 1982. The Upper Triassic fern Phlebopteris smithii (Daugherty) Arnold and its spores. Palynology 6, 203-219. https://doi.org/10.1080/01916122.1982.9989242

Badihagh, M.T., Uhl, D., 2019. The first occurrence of Phlebopteris dunkeri and P. woodwardii (Matoniaceae) from the middle Jurassic of Iran. Journal of Palaeogeography 8(6), 1-10. https://doi.org/10.1186/ s42501-018-0015-1

Barbacka, M., Ziaja, J., Wcisło-Luraniec, E., 2010. Taxonomy and palaeoecology of the Early Jurassic macroflora from Odrowąż, central Poland. Acta Geologica Polonica 60, 373-392.
Barbacka, M., Pacyna, G., Feldman-Olszewska, A., Ziaja, J., Bodor, E., 2014. Triassic-Jurassic flora of Poland; floristical support of climatic changes. Acta Geologica Polonica 64(3), 281-308. https://doi. org/10.2478/agp-2014-0015

Barbacka, M., Pacyna, G., Pieńkowski, G., Ziaja, J., 2016. New data about Matonia braunii (Göppert) Harris from the Early Jurassic of Poland and its ecology. Geological Quarterly 60(4), 857-868. https://doi.org/10.7306/gq.1322

Barbacka, M., Kustatscher, E., Bodor, E.R., 2019. Ferns of the Lower Jurassic from the Mecsek Mountains (Hungary): taxonomy and palaeoecology. PalZ 93(1), 151-185. https://doi.org/10.1007/ s12542-018-0430-8

Braun, F.W., 1843. Beiträge zur Urgeschichte der Pflanzen. In: Münster, G. (ed.), Beiträge zur Petrefaktenkunde, 6. pp. 1-46.

Brongniart, A., 1828-1837. Histoire des végétaux fossiles ou recherches botaniques et géologiques sur les végétaux renfermés dans les diverses couches du globe. G. Dufour et Ed. d'Ocagne (Vol. I), Crochard et Compie (Vol. II), Paris, Vol. I, 488 pp., Vol. II, 72 pp., Atlas: 166+30 plates.

Cronquist, A., Takhtajan, A., Zimmermann, W., 1966. On the higher taxa of Embryobionta. Taxon 15, 129-134. https://doi.org/10.2307/1217531

Goeppert, H.R., 1836. Die Fossilen Farrnkräuter. Verhandlungen Der Kaiserlichen Leopoldinisch-Carolinischen Academie der Naturforscher, Supplement 17, 1-488.

Goeppert, H.R., 1841. Die Gattungen der fossilen Pflanzen. Lieferung 1-2. Verlag von Henry und Cohen, Bonn, 70 pp.

Gothan, W., 1914. Die unter-liassische (rhätische) Flora der Umgegend von Nürnberg. Abhandlungen der Naturhistorischen Gesellschaft zu Nürnberg 19, 91-186.

Harris, T.M., 1926. The Rhaetic flora of Scoresby Sound East Greenland. Meddelelser om Grønland 68(2), 45-148.

Harris, T.M., 1931. The Fossil Flora of Scoresby Sound East Greenland. Part 1: Cryptogams (Exclusive of Lycopodiales). Meddelelser om Grønland 85(2), 1-102.

Harris, T.M., 1961. The Yorkshire Jurassic Flora I. Thallophyta - Pteridophyta. Trustees of the British Museum (Natural History), London, 212 pp.

Harris, T.M., 1980. The Yorkshire Jurassic fern Phlebopteris braunii (Goeppert) and its reference to Matonia R. Br. Bulletin of the British Museum (Natural History), Geology Series 33, 295-311.

Hirmer, M., Hoerhammer, L., 1936. Morphologie, Systematik und geographische Verbreitung der fossilen und rezenten Matoniaceen. Palaeontographica Abt. B 81, 1-70.

Jung, W., Knobloch, E., 1972. Die „STERNBERGOriginale" der Bayerischen Staatssammlung für Paläontologie und historische Geologie zu München. 
Mitteilungen der Bayerischen Staatssammlung für Paläontologie und historische Geologie 12, 105-111.

Klavins, S.D., Taylor, T.N., Taylor, E.L., 2004. Matoniaceous ferns (Gleicheniales) from the middle Triassic of Antarctica. Journal of Paleontology 78(1), 211-217.

Kramer, K.U., 1990. Matoniaceae. In: Kramer, K.U., Green, P.S. (eds), The Families and Genera of Vascular Plants. Vol. I. Pteridophytes and Gymnosperms. Springer, Berlin, Heidelberg, pp. 183-185. https://doi.org/10.1007/978-3-662-02604-5_33

Kuźniar, C., 1923. Rudy żelazne w okolicach Niekłania (Sur les minerais de fer dans les environs de Niekłań). Posiedzenia naukowe Państwowego Instytutu Geologicznego (Comptes-Rendus des Séances du Service Géologique de Pologne) 5, 6-8 (in Polish).

Kuźniar, C., 1924. O rudach żelaznych okolic Chlewisk (Sur les minerais de fer des environs de Chlewiska). Posiedzenia naukowe Państwowego Instytutu Geologicznego (Comptes-Rendus des Séances du Service Géologique de Pologne) 8, 1-2. (in Polish).

Kvaček, J., Dašková, J., 2010. Konijnenburgia, a new genus of the fern family Matoniaceae. Review of Palaeobotany and Palynology 158(3-4), 308-318. https://doi.org/10.1016/j.revpalbo.2009.10.002

Kvaček, J., Straková, M., 1997. Catalogue of fossil plants described in works of Kaspar M. Sternberg. National Museum, Prague, 201 pp.

Lilpop, J., Kostyniuk, M., 1957. Roślinność Polski w epokach minionych. Wydawnictwa Geologiczne, Warszawa, 319 pp.

Litwin, R.L., 1985. Fertile organs and in situ spores of ferns from the Late Triassic Chinle Formation of Arizona and New Mexico, with discussion of the associated dispersed spores. Review of Palaeobotany and Palynology 44, 101-146. https://doi. org/10.1016/0034-6667(85)90030-2

Lundblad, B., 1950. Studies in the Rhaeto-Liassic Floras of Sweden. I. Pteridophyta, Pteridospermae, and Cycadophyta from the mining district of NW Scania. Kungliga Svenska Vetenskapsakademiens Handlingar, Fjärde Series 1(8), 5-82.

Makarewiczówna, A., 1928. Étude sur la flore fossile du lias inférieur des environs d'Ostrowiec. Travaux de la Société des Science et des Letters de Wilno, Travaux de L'Institut de Géologie de l'Université de Wilno 4, 1-49 (In Polish, with French summary).

Möller, H., 1902. Bidrag till Borholms fossila flora. Pteridophyter. Lunds Universitets Årsskrift 38(2/5), 1-68.

Pacyna, G., 2013. Critical review of research on the Lower Jurassic flora of Poland. Acta Palaeobotanica 53(2), 141-163. https://doi.org/10.2478/acpa2013-0015

Pacyna, G., 2021. Matoniaceous ferns preserved in growth position in Lower Jurassic dune sandstones of the Holy Cross Mountains (Poland). Annales Societatis Geologorum Poloniae 91. https://doi. org/10.14241/asgp.2021.12
Pacyna, G., Zdebska, D., 2011. Nowe dane o rodzaju Ixostrobus Raciborski 1892 (nagozalążkowe, Czekanowskiales?) z dolnej jury Gromadzic (Góry Świętokrzyskie). In: Matyja, B.A., Wierzbowski, A., Ziółkowski, P. (eds), Jurassica IX, Materiały konferencyjne, Artykuły, Małogoszcz, 06-08.09.2011. Polskie Towarzystwo Geologiczne, Polska Grupa Robocza Systemu Jurajskiego, pp. 33-39.

Pacyna, G., Zdebska, D., Barbacka, M., Jarzynka, A., 2018. New data on Lower Jurassic plants from the Holy Cross Mountains (Central Poland). 10th European Palaeobotany and Palynology Conference, Dublin, Ireland, 12-17 August 2018, Program \& Abstracts, University College Dublin, p. 46.

Pieńkowski, G., 2004. The epicontinental Lower Jurassic of Poland. Polish Geological Institute Special Papers 12, 1-122.

Pieńkowski, G., 2006. Field trip B4 - Lower Jurassic marginal-marine and continental deposits - sedimentation, sequences, and ecosystems. In: Wierzbowski, A., Aubrecht, R., Golonka, J., Gutowski, J., Krobicki, M., Matyja, B.A., Pieńkowski, G., Uchman, A. (eds), Jurassic of Poland and Adjacent Slovakian Carpathians. Field trip guidebook of 7 th International Congress of the Jurassic System. Polish Geological Institute, Warszawa, pp. 207-235.

Popa, M., 1997. Liassic ferns from the Steierdorf Formation, Anina, Romania. In: Herngreen, G.F.W. (ed.), Proceedings of the $4^{\text {th }}$ European Palaeobotanical and Palynological Conference. Mededelinger Nederlands Instituut voor Toegepaste Geowetenschappen TNO 58, 139-147.

PPG I, 2016. A community-derived classification for extant lycophytes and ferns. Journal of Systematics and Evolution 54, 563-603. https://doi.org/10.1111/ jse. 12229

Presl, K.B., 1848. Die Gefässbündel im Stipes der Farren. Abhandlungen der Königlichen Böhmischen Gesellschaft der Wissenschaften 5(5), 307-356.

Raciborski, M., 1891. Flora retycka północnego stoku Gór Świętokrzyskich. Rozprawy Wydziału matematyczno-przyrodniczego Akademii Umiejętności w Krakowie 23, 292-326 (in Polish).

Raciborski, M., 1892. Przyczynek do flory retyckiej Polski. Rozprawy Wydziału matematyczno-przyrodniczego Akademii Umiejętności w Krakowie 22, 345-360 (in Polish).

Raciborski, M., 1894. The fossil flora of Kraków's refractory clays. Part I. Cryptogamous plants (Archaegoniatae). Pamiętnik matematyczno-przyrodniczy Akademii Umiejętności 18, 1-101 (in Polish).

Reymanówna, M., 1963. The Jurassic flora from Grojec near Cracow in Poland. Part I. Acta Palaeobotanica 4, 9-48.

Reymanówna, M., Wcisło-Luraniec, E., Ichas-Ziaja, J., 1987. The Liassic flora of the Holy Cross Mts. In: 14 International Botanical Congress Berlin, Guide to Excursion no. 24 "From the Jurassic to the Holocene: the palaeoflora and palaeo-ecology of $\mathrm{W}$ and S Poland", pp. 46-54. 
Schenk, A., 1865-1867. Die fossile Flora der Grenzschichten des Keupers und Lias Frankens. Kreidel, Wiesbaden, $231 \mathrm{pp}$.

Schenk, A., 1888. Die fossilen pflanzenreste. Breslau, Verlag von Eduard Trewendt, $284 \mathrm{pp}$.

Schimper, W.P., 1869-1874. Traite de Paleontologie vegetale ou la flore du monde primitif dans ses rapports avec les formations geologiques et la flore du monde actuel. Vol. 1 (1869), 738 pp.; Vol. 2 (18701872), 869 pp.; Vol. 3 (1874), 966 pp.; Atlas (1874), 110 pls. J.B. Baillere et Fils, Paris.

Schweitzer, H.J., 1978. Die Raeto-Jurassischen Floren des Iran und Afghanistans: 5. Todites princeps, Thaumatopteris brauniana und Phlebopteris polypodioides. Palaeontographica Abt. B 168(1-3), 17-60.

Schweitzer, H-J., Schweitzer, U., Kirchner, M., Van Konijnenburg-van Cittert, J.H.A., Van der Burgh, J., Ashraf, R.A., 2009. The Rhaeto-Jurassic flora of Iran and Afghanistan. 14. Pterophyta - Leptosporangiatae. Palaeontographica Abt. B 279(1-6), 1-108. https://doi.org/10.1127/palb/279/2009/1

Seward, A.C., 1899. On the structure and affinities of Matonia pectinata, R. Br., with notes on the geological history of the Matonineae. Philosophical Transactions of the Royal Society B: Biological Sciences 191, 171-209. https://doi.org/10.1098/ rstb.1899.0006

Smith, A.R., Pryer, K.M., Schuettpelz, E., Korall, P., Schneider, H., Wolf, P.G., 2006. A classification for extant ferns. Taxon 55(3), 705-731. https://doi. org/10.2307/25065646

Sternberg, K.M., 1820-1838. Versuch einer geognostisch botanischen Darstellung der Flora der Vorwelt. Fr. Fleischer, Leipzig und Prag, 220 pp.

Taylor, T.N., Taylor, E.L., Krings, M., 2009. Paleobotany, The Biology and Evolution of Fossil Plants, Second Edition. Academic Press, Amsterdam, 1230 pp.
Tidwell, W.D., Ash, S.R., 1994. A review of selected Triassic to Early Cretaceous ferns. Journal of Plant Research 107(4), 417-442. https://doi.org/10.1007/ bf02344066

Tralau, H., 1965. Phlebopteris angustiloba (Presl) Hirmer et Höhammer. Botaniska Notiser 118(4), 373-376.

Turland, N.J., Wiersema, J.H., Barrie, F.R., Greuter, W., Hawksworth, D.L., Herendeen, P.S., Knapp, S., Kusber, W-H., Li, D-Z., Marhold, K., May, T.W., McNeill, J., Monro, A.M., Prado, J., Price, M.J., Smith, G.F. (eds), 2018. International Code of Nomenclature for algae, fungi, and plants (Shenzhen Code) adopted by the Nineteenth International Botanical Congress Shenzhen, China, July 2017. Regnum Vegetabile 159. Koeltz Botanical Books, Glashütten, 254 pp. https://doi.org/10.12705/ code. 2018

Wallich, N., 1830. Plantae Asiaticae Rariores: or, Descriptions and figures of a select number of unpublished East Indian plants. Vol. 1. Richard Taylor, London, 100 pp.

Weber, R., 1968. Die fossile Flora der Rhät-Lias Übergangsschichten von Bayreuth (Oberfranken) unter besonderer Berücksichtigung der Coenologie. Erlanger Geologische Abhandlungen 72, 1-73.

Van Konijnenburg-van Cittert, J.H.A., 1993. A review of the Matoniaceae based on in situ spores. Review of Palaeobotany and Palynology 78(3-4), 235-267. https://doi.org/10.1016/0034-6667(93)90066-4

Van Konijnenburg-van Cittert, J.H.A., Pott, C., Schmeißner, S., Dütsch, G., Kustatscher, E., 2020. Ferns and fern allies in the Rhaetian flora of Wüstenwelsberg, Bavaria, Germany. Review of Palaeobotany and Palynology 273, 104147. https:// doi.org/10.1016/j.revpalbo.2019.104147

Ziaja, J. 2006. Lower Jurassic spores and pollen grains from Odrowąż, Mesozoic margin of the Holy Cross Mountains, Poland. Acta Palaeobotanica 46(1), 3-83. 